\title{
NOV inhibits proliferation while promoting apoptosis and migration in osteosarcoma cell lines through p38/MAPK and JNK/MAPK pathways
}

\author{
JUAN YAO, YAGUANG WENG, SHUJUAN YAN, MENGYI HOU, HAO WANG, QIONG SHI and GUOWEI ZUO
}

Key Laboratory of Diagnostic Medicine Designated by the Chinese Ministry of Education, Chongqing Medical University, Chongqing 400016, P.R. China

Received April 22, 2015; Accepted June 17, 2015

DOI: 10.3892/or.2015.4153

\begin{abstract}
The nephroblastoma overexpressed (NOV) gene, a member of the $C C N$ gene family that encodes secreted proteins involved in a variety of processes including tumorigenesis, is often altered in a variety of tumors, including osteosarcoma. Recent studies indicated that NOV promotes osteosarcoma metastasis, but its biological functions and molecular mechanisms on osteosarcoma proliferation have yet to be fully elucidated. The aim of the present study was to examine the role of NOV in osteosarcoma biology. Reverse transcriptionpolymerase chain reaction (RT-PCR) and western blot analysis were performed to characterize the endogenous expression of NOV in osteosarcoma cell lines. Recombinant adenovirus expressing NOV/siNOV (AdNOV/AdsiNOV) was used to infect osteosarcoma cell lines with a relatively low/high endogenous NOV expression to determine the functional relevance of NOV expression to osteosarcoma cell growth and migration in vitro, respectively. As a result, osteosarcoma cell proliferation was significantly reduced by NOV upregulation, indicated by 3-(4,5-dimethylthiazol-2-yl)-2, 5-diphenyltrazolium bromide (MTT), colony forming assay and cell cycle analysis. Cell apoptosis was markedly induced, as indicated by Hoechst 33258 staining assay and flow cytometry (FCM) detection. Despite the antiproliferative effect, NOV-transfected osteosarcoma cells exhibited increased migration ability. The possible molecular mechanisms underlying the biological role of NOV were also investigated. The results demonstrated that NOV increased the phosphorylation of p38 and c-Jun N-terminal kinase (JNK) mitogen-actived protein kinases (MAPKs) in osteosarcoma cell lines. When the phosphorylation of p38 and JNK were inhibited by SB203580 (p38 inhibitor) or SP600125
\end{abstract}

Correspondence to: Dr Guowei Zuo, Department of Laboratory Medicine, Chongqing Medical University, 1 Yixueyuan Road, Yuzhong, Chongqing 400016, P.R. China

E-mail: 17305105@qq.com

Key words: osteosarcoma, nephroblastoma overexpressed gene, cell proliferation, apoptosis, migration, tumor metastasis
(JNK inhibitor), respectively, the NOV-induced proliferation inhibition and cell apoptosis were reversed. In conclusion, the results revealed that NOV regulates the tumor growth of osteosarcoma cells through activation of the MAPK signaling pathway and promotes osteosarcoma cell migration in vitro.

\section{Introduction}

Osteosarcoma is the most common primary bone cancer in adolescents and young adults (1). Although treatment modalities have been improved over the past decades, the survival rate of these patients has limited improvement and the 3-5 years of survival rate after amputation is only $5-20 \%(2,3)$. Therefore, it is particularly important to understand the pathogenesis of osteosarcoma in order to develop novel treatment strategies.

Nephroblastoma overexpressed (NOV) gene maps on chromosome $8 \mathrm{q} 24.1$ and was originally identified as aberrantly expressed in avian nephroblastoma induced by myeloblastosisassociated virus (4). NOV belongs to the CCN family of genes, which comprises five additional members: cystein-rich protein 61 (Cyr61), connective tissue growth factor (CTGF), Wnt-1-induced secreted protein (WISP)-1, WISP-2 and WISP-3 (5). The $C C N$ genes encode secreted proteins of $35-48 \mathrm{kDa}$ associated with the extracellular matrix (ECM) and cell membrane, which are involved in the regulation of various cell functions such as proliferation, differentiation, migration, attachment, angiogenesis and tumorigenesis (6). These genes are expressed in all derivatives of the three embryonic sheets and are involved in the development of kidney, nervous system, muscle, bone marrow, cartilage and bone (7).

Unlike other CCN family members Cyr61 and CTGF, NOV has been less studied and the functions of NOV protein among different tissues are inconsistent and sometimes controversial. NOV was originally described as antiproliferative (8) and its expression was associated with differentiation and growth arrest in Wilm's tumor (9), rhabdomyosarcomas (10), cartilaginous tumors (11), renal cell carcinoma (12) and Ewing sarcoma (13), while more recent data associate NOV expression with increased proliferative index of 3 T3 fibroblast $(14,15)$ and tissue samples of prostate. Furthermore, although NOV reduced the growth rate of renal cell carcinoma and Ewing sarcoma transfectants in vitro, NOV expression was associated with 
poor prognosis and shown to increase cell motility, resulting in enhanced metastatic potential in these tumors $(12,13)$. It has been shown that in osteosarcoma NOV is inversely associated with the expression of liver/bone/kidney alkaline phosphatase isoform (16), an early marker of osteoblastic differentiation, and has prognostic value of in osteosarcoma (17). Nevertheless, the effect of NOV on osteosarcoma cell biological behaviors and the underlying molecular mechanisms remain unclear.

P38/MAPK and JNK/MAPK signaling pathways, which have been confirmed to be tightly associated with tumor cell apoptosis $(18,19)$, including osteosarcoma $(20,21)$, are two important intracellular signaling pathways. Certain studies have suggested that NOV was able to induce cell apoptosis or growth inhibition in various types of cancer through the activation of MAPKs signaling, such as choriocarcinoma, nephroblastoma and Ewing sarcoma (13). Howerover, whether p38/MPAK and JNK/MAPK signaling pathway activation is involved in the NOV-induced effects of osteosarcoma remains to be elucidated.

Based on the abovementioned studies, we aimed to discuss the effects of recombinant adenovirus $(22,23)$-mediated NOV overexpression or silencing on osteosarcoma cell lines, as well as to investigate the probable molecular mechanisms underlying these effects. Our studies found that NOV inhibited the proliferation while promoting the apoptosis and migration of osteosarcoma cell lines in vitro and the activation of p38/MAPK and JNK/MAPK signal may be involved in these processes. These results offer a new approach for the treatment of osteosarcoma.

\section{Materials and methods}

Cell culture and reagents. The 143B, U2OS, MG-63 and SaOS2 human osteosarcoma cell lines were purchased from the American Type Culture Collection (ATCC, Manassas, VA, USA). The cells were maintained in Dulbecco's modified Eagle's medium (DMEM; Utah, HyClone, UT, USA) supplemented with $10 \%$ fetal bovine serum (FBS; Gibco Life Technologies, Carlsbad, CA, USA) and $100 \mathrm{U} / \mathrm{ml}$ streptomycin/penicillin at $37^{\circ} \mathrm{C}$ in $5 \% \mathrm{CO}_{2}$. Recombinant adenovirus expressing green fluorescent protein (AdGFP), red fluorescent protein (AdRFP), NOV (AdNOV) with GFP and recombinant adenovirus expressing siRNA targeted NOV (AdsiNOV) with RFP were donated by Professor T.-C. He, University of Chicago Medical Center. 3-(4,5)-Dimethylthiazol(-z-yl)-3,5diphenyltetrazolium bromide (MTT) and dimethyl sulphoxide (DMSO) were obtained from Solarbio Biology (Beijing, China). TRIzol reagent was purchased from Invitrogen-Life Technologies (Carlsbad, CA, USA). Reverse transcription-polymerase chain reaction (RT-PCR) reagents were purchased from Takara (Otsu, Japan). Reverse transcription-quantitative PCR (RT-qPCR) reagents were purchased from Thermo Fisher Scientific, (Waltham, MA, USA). Hoechst 33258 and western blot detection reagents were purchased from the Beyotime Institute of Biotechnology (Jiangsu, China). Rabbit anti-NOV monoclonal antibody was purchased from Abcam (Abcam, Cambridge, MA, USA). Mouse anti-Bax, anti-Bcl-2 monoclonal antibodies were purchased from Santa Cruz Biothechnology, Inc. (Santa Cruz, CA, USA). Rabbit anti-p38, anti-phosphor-p38, anti-JNK, anti-phosphor-JNK polyclonal antibodies were purchased from Immunoway (Immunoway, Newark, DE, USA). Mouse anti- $\beta$-actin monoclonal antibody, and secondary antibodies including HRP-conjugated goat anti-mouse IgG antibody and anti-rabbit IgG antibody were purchased from Zhongshan Goldenbridge Biotechnology (Beijing, China). BeyoECL was purchased from Millipore (Billerica, MA, USA).

Adenovirus infection. Osteosarcoma cells (143B) were infected with recombinant adenovirus AdNOV and negative control AdGFP, respectively. MG63 osteosarcoma cells were infected with AdsiNOV and negative control AdRFP, respectively. After being infected for 8-12 h, the medium was replaced with serum-free or low serum DMEM followed by continued cell culturing for subsequent experiments.

Cell viability assay. Cell proliferation was analyzed with the MTT assay. Briefly, the cells infected with different adenovirus or blank control were incubated in 96-well plates at a density of $1 \times 10^{4}$ cells/well with DMEM supplemented with $10 \%$ FBS. At the indicated time-points $(24,48$, and $72 \mathrm{~h}), 20 \mu \mathrm{l}$ of the MTT reagent $(5 \mathrm{mg} / \mathrm{ml})$ was added to each well and the mixture was incubated for another $4 \mathrm{~h}$. The MTT solution was then removed and formazan was dissolved in DMSO for $10 \mathrm{~min}$ at room temperature and the color reaction was measured at $492 \mathrm{~nm}$ with enzyme immunoassay analyzer (Bio-Rad, Hercules, CA, USA). The experiment was repeated three times and the proliferative activities were calculated for each well.

Colony-forming assay. Osteosarcoma cell lines during the log growth stage were seeded in 6-well culture plates $\left(4 \times 10^{2}\right.$ cells/well) and treated with AdNOV/AdsiNOV, respectively. After incubation for 2 weeks, the cells were stained with crystal violet and clones were counted. The colony-forming rate was obtained using the formula: (colony number/seeded cell number) $\mathrm{x} 100 \%$. The experiment was repeated three times.

Cell cycle and apoptosis analysis. Cell cycle and apoptosis analysis were assessed by FCM. Briefly, the cells were seeded in 6-well plates at a density of $2 \times 10^{5}$ cells/well and treated with relevant adenovirus for $48 \mathrm{~h}$. Log-phase cells from each group were harvested by centrifugation. After being washed twice with ice-cold PBS and resuspended, an aliquot of samples were fixed with pre-cold $75 \%$ enthanol at $4^{\circ} \mathrm{C}$ overnight. The remaining samples were added into apoptosis analysis solution and then analyzed by a FACSVantage SE flow cytometer (Becton-Dickinson, San Jose, CA, USA). Each experiment was performed three times.

Hoechst 33258 staining assay. The Hoechst staining assay was performed according to the manufacturer's instructions using the Hoechst 33258. The cells seeded in 24-well plates were treated with adenovirus for $48 \mathrm{~h}$ and then washed twice with cold PBS. The cells were fixed with $4 \%$ paraformaldehyde for $10 \mathrm{~min}$ and continued to be washed twice with PBS. Two hundred mililiters of 1:1,000 Hoechst staining solution was added to each well and the cells were incubated for $30 \mathrm{~min}$ at room temperature in the dark. The cells were then washed twice with PBS and viewed under a UV microscope. Each experiment was performed three times. 
Table I. The primer sequences and their product lengths in RT-PCR.

\begin{tabular}{llc}
\hline Gene & \multicolumn{1}{c}{ Primer sequences } & Length of product (bp) \\
\hline GAPDH & F: 5'-CAG CGA CAC CCA CTC CTC-3' & 120 \\
& R: 5'-TGA GGT CCA CCA CCC TGT-3' \\
NOV & F: 5'-ACC TTC CTG CTT CTC CAT C-3' \\
& R: 5'-CTC CCA GTG AAT CCT CCT C-3' \\
BAX & F: 5'-CCC TTT TGC TTC AGG GTT TC-3' \\
& R: 5'-TGT TAC TGT CCA GTT CGT CC-3' \\
BCL-2 & F: 5'-GAG ACA GCC AGG AGA AAT CA-3' \\
& R: 5'-CCTGTGGATGACTGAGTACC-3' & 150 \\
\hline NOV, nephroblastoma overexpressed; BCL-2, B cell lymphoma-2; BAX, Bcl-2-associated X protein; GAPDH, glyceraldehyde-3-phosphate &
\end{tabular}

Transwell chamber migration assay. Cell migration assay were performed by 24 -well Transwell chambers $(8 \mu \mathrm{m}$ pore size; Millipore). Briefly, the cells $\left(5 \times 10^{4} / 400 \mu \mathrm{l}\right)$ treated with different adenovirus in serum-free DMEM were seeded onto the upper chambers and fresh DMEM $(600 \mu 1 /$ well $)$ containing $20 \%$ FBS was added to the bottom chambers. After $24 \mathrm{~h}$, cells that migrated to the underside of the filter were fixed with methanol and stained with crystal violet, and counted under brightfield microscopy. The experiments were repeated three times.

RNA extraction, RT-PCR and RT-qPCR analysis. Total RNA was extracted from osteosarcoma cells in different groups using TRIzol reagent, according to the manufacturer's instructions. First-strand DNA was synthesized using the Reverse Transcriptase M-MLV (RNase H) kit with random hexamer primers. Touchdown PCR analysis determining the gene expression level was performed under the following conditions: $95^{\circ} \mathrm{C}$ x 5 min for one cycle, 12 cycles at $95^{\circ} \mathrm{C}$ x $30 \mathrm{sec}$, $68^{\circ} \mathrm{C} \times 30 \mathrm{sec}$ (with a decrease of 1 degree/cycle) and $72^{\circ} \mathrm{C} \times 30 \mathrm{sec}$ and 25 cycles at $95^{\circ} \mathrm{C} \times 30 \mathrm{sec}, 55^{\circ} \mathrm{C} \times 30 \mathrm{sec}$, and $72^{\circ} \mathrm{C} \times 30 \mathrm{sec}, 72^{\circ} \mathrm{C}$ x $10 \mathrm{~min}$ for 1 cycle. PCR products were separated by electrophoresis on a $2 \%$ agarose gel. The expression level of mRNA were normalized to GAPDH. RT-qPCR was run in the Rotor-Gene 6000 Real-Time PCR machine (Corbett Research, Sydney, Australia) using SYBR Premix Ex Taq (Thermo) with the following protocol: initial activation of HotStar Taq DNA polymerase at $95^{\circ} \mathrm{C}$ for $10 \mathrm{~min}$, then 45 cycles of $95^{\circ} \mathrm{C}$ for $5 \mathrm{sec}$ and $60^{\circ} \mathrm{C}$ for $20 \mathrm{sec}$. GAPDH was used as an internal control. The primer efficiencies were confirmed to be high (>90\%) and comparable (Table I). Data were analyzed according to the $2^{-\Delta \Delta \mathrm{Ct}}$ method. The expression level of mRNA were normalized to GAPDH. Three separate experiments were performed for each group.

Western blot assay. Briefly, osteosarcoma cells with different treatments were lysed with RIPA buffer, then centrifuged for $30 \mathrm{~min}$ at $4^{\circ} \mathrm{C}$ and supernatants were collected. The protein concentration was determined by the BCA assay. Cell extracts were boiled for $10 \mathrm{~min}$ in loading buffer and then an equal amount of cell extracts was separated on $10 \%$ SDS-PAGE gels and transferred subsequently onto PVDF membranes. After blocking with 5\% BSA (Bovine Serum Albumin, Solarbio) in TBST, the membranes were probed with the primary antibody and incubated at $4^{\circ} \mathrm{C}$ overnight. Horseradish peroxidase-conjugated secondary antibodies were added at a dilution ratio of 1:5,000 and incubated at $37^{\circ} \mathrm{C}$ for $1 \mathrm{~h}$. Protein levels were quantified using the SuperSignal West Pico Chemiluminescent Substrate kit. Three separate experiments were performed for each group.

Inhibition of p38 and JNK with specific inhibitors and its effects on the NOV-induced antiproliferative effect and apoptosis of $143 B$ cells. The cells were treated with $10 \mu \mathrm{M}$ SB203580 (p38 inhibitor) or $20 \mu \mathrm{M}$ SP600125 (JNK inhibitor) for $30 \mathrm{~min}$, followed by treatment with AdGFP or AdNOV for the indicated time points. Following treatment for $48 \mathrm{~h}$, the phosphorylation of p38 and JNK was detected by western blot analysis. At the same time, the expression of Bax and Bcl-2 was detected by western blot analysis. The experiments were repeated three times.

Statistical analysis. Data are presented as the means \pm standard deviation (SD) from at least three independent experiments. One-way analysis of variance (ANOVA) was used to analyze the differences between groups and the LSD method of multiple comparisons was used when the probability for ANOVA was statistically significant using GraphPad Prism 5 and SPSS 17.0. Statistical significance was set at $\mathrm{P}<0.05$.

\section{Results}

The endogenous expression of NOV in osteosarcoma cell lines. In the present study, the endogenous expression of NOV in human 143B, U2OS, MG-63 and SaOS2 osteosarcoma cell lines was evaluated using RT-PCR analysis (Fig. 1A). As shown in Fig. 1A, the mRNA expression level of NOV in these osteosarcoma cell lines was different. The expression level was significantly higher in MG63 cells although obviously lower in 143B cells as compared to the remaining cells. The result was confirmed by RT-qPCR (Fig. 1B) and western blot assays (Fig. 1C). Thus, we selected 143B and MG63 

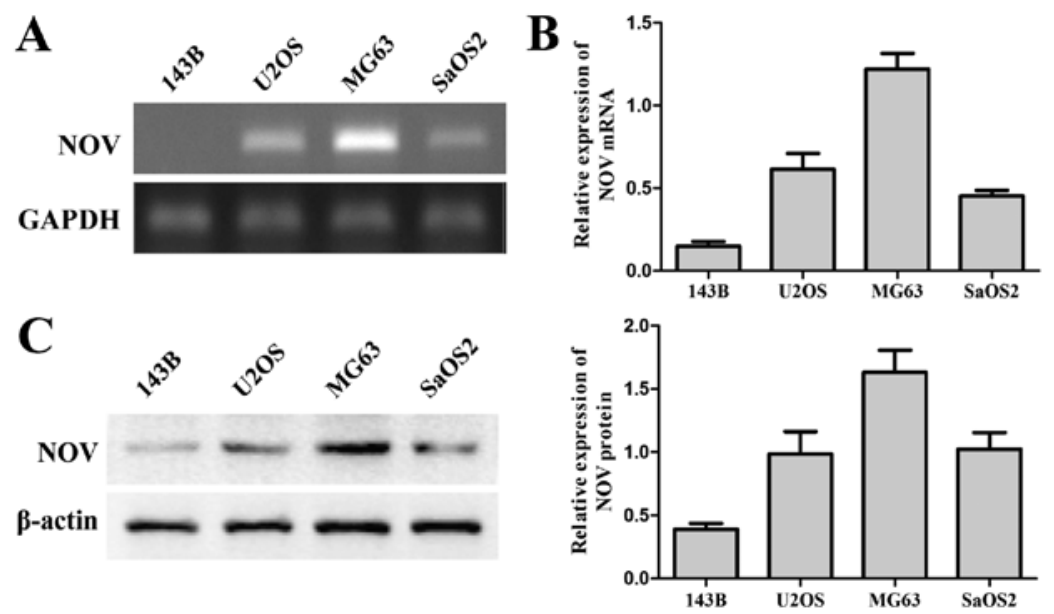

Figure 1. The endogenous expression of NOV was quite different in the four osteosarcoma cell lines. (A) NOV mRNA in different types of human osteosarcoma cell lines was detected by RT-PCR. (B) NOV mRNA was detected by RT-qPCR. Data are reported as mean values \pm SD of three individual measurements. (C) NOV protein was detected by western blot analysis. Data are shown as mean values \pm SD of three individual measurements.

A

$143 B$

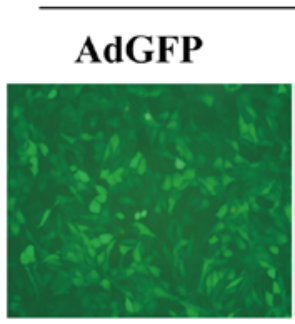

\section{AdNOV}
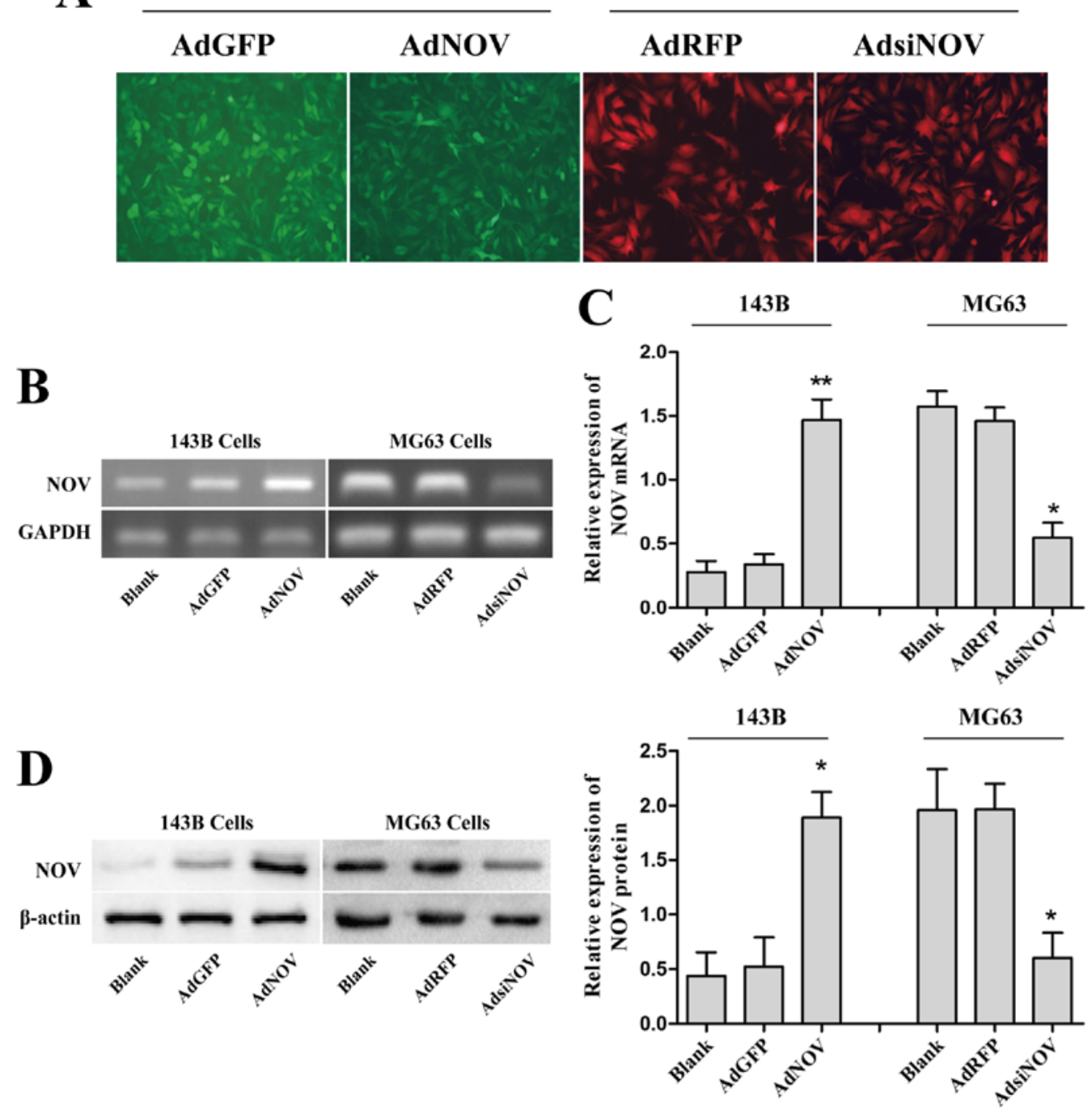

Figure 2. NOV was successfully overexpressed in 143B cells and interfered in MG63 cells. (A) Constructed adenovirus vector AdNOV and AdsiNOV was used to infect the 143B and MG63 cell lines, respectively. The infection efficiency of AdNOV and AdsiNOV (MOI=100) in 143B and MG63 cell lines was $>80 \%$ under fluorescence microscopy. (B) RT-PCR, (C) RT-qPCR and (D) western blot assays were performed at $48 \mathrm{~h}$ recovery to measure the expression of NOV, showing that an obvious increase of NOV expression was observed in the AdNOV group compared with the AdGFP and blank groups in 143B cells $\left({ }^{* *} \mathrm{P}<0.01\right.$ and ${ }^{*} \mathrm{P}<0.05$ vs. AdGFP group), while a marked decrease of NOV expression was found in the AdsiNOV group compared with the Ad-RFP and blank groups in MG63 cells ("P<0.05 vs. AdRFP group). No difference was found between the AdGFP/AdRFP and blank groups in $143 \mathrm{~B}$ and MG63 cell lines $(\mathrm{P}>0.05)$. Data are shown as mean values $\pm \mathrm{SD}$ of three individual measurements. 
osteosarcoma cell lines for infection with the AdNOV and AdsiNOV adenovirus, respectively.

NOV is successfully overexpressed in $143 \mathrm{~B}$ cells and interfered in MG63 cells. To identify the role of NOV in osteosarcoma cell lines, recombinant adenovirus AdNOV and AdsiNOV were used to infect 143B and MG63 cell lines, respectively. In the present study, the infection efficiency of AdNOV and AdsiNOV in 143B and MG63 cell lines was $>60 \%$ under fluorescence microscopy (Fig. 2A). In addition, RT-PCR (Fig. 2B), RT-qPCR (Fig. 2C) and western blot assays (Fig. 2D) were performed at $48 \mathrm{~h}$ recovery to measure the expression level of NOV after adenovirus infection. An obvious increase of NOV expression was observed in the AdNOV group compared with the AdGFP and control groups $(\mathrm{P}<0.01$ and $\mathrm{P}<0.05)$ in 143B cells, while a marked decrease of NOV expression was found in the AdsiNOV group compared with the AdRFP and control groups in MG-63 cells $(\mathrm{P}<0.05)$ (Fig. 2B and $\mathrm{C})$. These data indicated that NOV was successfully overexpressed in 143B cells and interfered in MG63 cells.

NOV inhibits cell viability of osteosarcoma cells. To investigate the effects of NOV on cell growth, osteosarcoma cells were treated with AdNOV and AdsiNOV, respectively, for 24, 48 and $72 \mathrm{~h}$, and cell viability was examined by MTT assay (Fig. 3A and B). As shown in Fig. 3A and B, the cell viability of $143 \mathrm{~B}$ cells treated with AdNOV was significantly inhibited at $48 \mathrm{~h}(\mathrm{P}<0.05)$ and was more significant at $72 \mathrm{~h}$ $(\mathrm{P}<0.01)$, whereas the cell viability of MG63 cells treated with AdsiNOV was significantly promoted at $48 \mathrm{~h}(\mathrm{P}<0.05)$ and $72 \mathrm{~h}(\mathrm{P}<0.05)$. Thus, we selected $48 \mathrm{~h}$ as the time-point for the remaining experiments. Furthermore, after treatment with AdNOV for 2 weeks, we found a significant decrease in colony formation in the AdNOV group and the colonyformation rate decreased by $23 \%$ in $143 \mathrm{~B}$ cells compared with that of the AdGFP and control groups $(\mathrm{P}<0.01)$, while a slight increase in colony formation in the AdsiNOV group in MG63 cells, compared with that of the AdRFP and control groups ( $\mathrm{P}>0.05$, Fig. 3C).

NOV induces cell cycle arrest in osteosarcoma cell lines. Cell cycle arrest plays a crucial role in the process of cell proliferation. Flow cytometric assay was used to detect the change of the cell cycle induced by NOV expression (Fig. 3D). The data showed that NOV overexpression decreased the percentage of $143 \mathrm{~B}$ cells in the $\mathrm{S}$ phase from $(35.14 \pm 3.29)$ to $(23.83 \pm 4.66) \%(\mathrm{P}<0.01)$ compared to the AdGFP group, and increased the percentage of $\mathrm{G} 1$ phase from $(63.61 \pm 4.55)$ to $(73.92 \pm 1.22) \%(\mathrm{P}<0.05)$ compared to the AdGFP group, respectively. Conversely, knockdown of NOV expression through RNA interference in MG63 cells, led to the percentage of MG63 cells in the $S$ phase being increased from $(19.32 \pm 5.16)$ to $(39.07 \pm 4.16) \%(\mathrm{P}<0.01)$ and the percentage of $\mathrm{G} 1$ phase was decreased from $(58.15 \pm 2.33)$ to $(43.29 \pm 5.37) \%(\mathrm{P}<0.05)$ compared to the AdRFP group, respectively (Fig. 3D).

NOV stimulates apoptosis of osteosarcoma cell lines in vitro. To evaluate apoptotic cell death in osteosarcoma cells after AdNOV/AdsiNOV treatment, flow cytometric assay (Fig. 4A), Hoechst staining (Fig. 4B), RT-qPCR (Fig. 4C and D) and western blot analysis (Fig. 4E) were performed. In Fig. 4A it is shown that the apoptotic rate of 143B cells was significantly increased from $(5.23 \pm 2.61)$ to $(11.91 \pm 2.29) \%(\mathrm{P}<0.01)$ compared to the AdGFP groups following treatment with AdNOV for $48 \mathrm{~h}$, whereas the apoptotic rate of MG63 cells was significantly reduced as compared to that of the AdRFP groups after AdsiNOV treatment for $48 \mathrm{~h}(\mathrm{P}<0.05)$. Staining with Hoechst 33258 (Fig. 4B) was used to visualise the apoptosis induced by NOV expression, and extensive nuclear condensation and cell fragmentation were observed. Moreover, a significant increase in Bax expression and a parallel Bcl-2 decrease was observed in 143B cells after NOV overexpression, while the contrary result was evident in MG63 cells after AdsiNOV infection $(\mathrm{P}<0.05$ and $\mathrm{P}<0.01$, Fig. 4C-E).

NOV promotes osteosarcoma cell migration in vitro. Cell migration plays a crucial role in the process of tumor metastasis. In the present study, Transwell migration assay was used to detect the change in cell migration induced by NOV. After treatment with adenovirus for $24 \mathrm{~h}$, the number of transmembrane cells in the NOV upregulation group increased significantly compared with the control group in 143B and MG63 cells $(\mathrm{P}<0.05$ and $\mathrm{P}<0.01$, Fig. 5).

NOV-induced activation of the MAPK signaling pathway in osteosarcoma cell lines. It has been previously reported that activation of $\mathrm{p} 38 / \mathrm{MAPK}$ and JNK/MAPK signaling pathway was associated with cell apoptosis. To determine whether NOV expression is involved in activation of the MAPK signaling pathway in osteosarcoma cell lines, we detected and analyzed the phosphorylation of MAPKs in cell lysates of osteosarcoma cells in different groups by western blot analysis (Fig. 6A and B). The results showed that NOV overexpression enhanced the phosphorylation of p38 and JNK/MAPKs in 143B cells, whereas downregulated NOV had an obvious suppressant effect on the phosphorylation of MAPKs in MG63 cells $(\mathrm{P}<0.05$ and $\mathrm{P}<0.01$, Fig. $6 \mathrm{~A}$ and $\mathrm{B}$ ). These results demonstrated that NOV enhances the activity of the MAPK signaling pathway (p38 and JNK) in osteosarcoma cell lines.

Impact of the inhibition of MAPK signaling on NOV-induced apoptosis of osteosarcoma cells. To investigate whether activation of the MAPK signaling pathway is involved in the NOV-induced apoptosis of osteosarcoma cells, the specific inhibitors of p38 (SB203580) and JNK (SP600125) were used to pre-treat the 143B cells. We detected the phosphorylation of MAPKs by western blot analysis (Fig. 7A) and found that the NOV-induced phosphorylation of p38 and JNK was reversed by SB203580 $(\mathrm{P}<0.05)$ and SP600125 $(\mathrm{P}<0.05)$, respectively. Cell viability was measured by MTT assay (Fig. 7B). We found that both SB203580 and SP600125 significantly suppressed the NOV-induced antiproliferative effect at $48 \mathrm{~h}(\mathrm{P}<0.05)$ and $72 \mathrm{~h}(\mathrm{P}<0.05)$. At the same time, we detected changes in the expression levels of Bax and Bcl-2 in the presence and absence of SB203580 or SP600125 (Fig. 7C). We found that the NOV-induced upregulated expression of Bax was reversed by SB203580 $(\mathrm{P}<0.05)$ and SP600125 $(\mathrm{P}<0.05)$, while the downregulated expression of Bcl-2 was also reversed by SB203580 $(\mathrm{P}<0.05)$ and SP600125 $(\mathrm{P}<0.01)$ in $143 \mathrm{~B}$ cells. These results suggested that the promotive role of NOV in the apoptosis of 
A

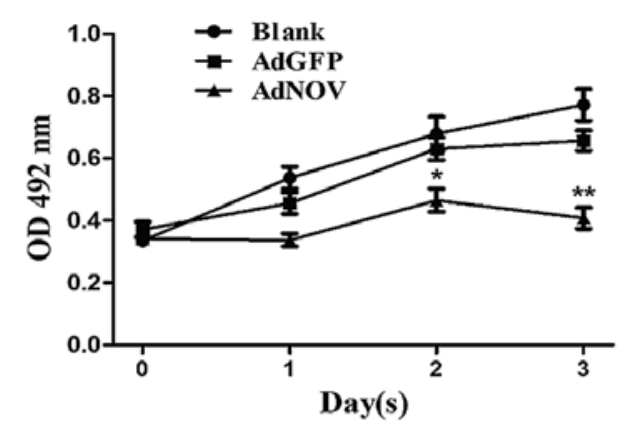

C
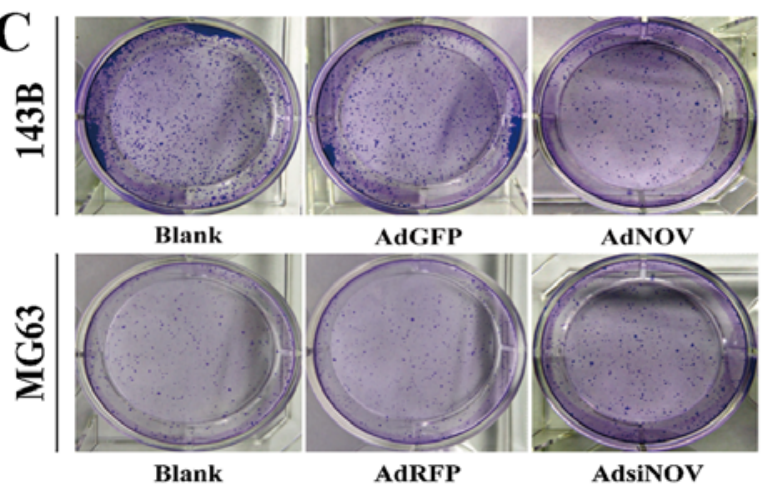

$143 B$

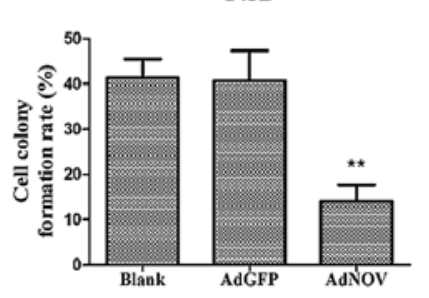

143B

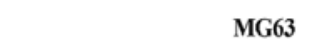

Figure 3. NOV inhibits the proliferation and cell cycle of human osteosarcoma cell lines. (A) 143B and (B) MG63 cells were infected with AdNOV or AdsiNOV for 24, 48 and $72 \mathrm{~h}$. At the end of the indicated time, cell viability was determined by MTT assays. The results show the mean absorbance \pm SD of three independent experiments. ${ }^{* *} \mathrm{P}<0.01$ and ${ }^{*} \mathrm{P}<0.05$ vs. AdGFP group or AdRFP group). (C) Colony forming assay of the osteosarcoma cell lines treated with AdNOV or AdsiNOV. The number of colonies decreased significantly in the AdNOV group in 143B cells and had a marked increase in the AdsiNOV group in MG63 cells. Representative images of the colony-forming unit are presented in the upper panel, and colony-forming rates for each group are quantified in the lower panel. The colony-forming rate was obtained as mentioned in Materials and methods. The experiment was repeated three times. ${ }^{* *} \mathrm{P}<0.01 \mathrm{vs}$. AdGFP group, ${ }^{\# P}>0.05$ vs. AdRFP group). (D) Osteosarcoma cell lines were infected with AdNOV or AdsiNOV for $48 \mathrm{~h}$. Cell cycle distribution was analyzed by flow cytometry. The data are presented as the means $\pm \mathrm{SD}(\mathrm{n}=3)$. The assay was performed in triplicate. $\left({ }^{* * *} \mathrm{P}<0.01\right.$ and ${ }^{*} \mathrm{P}<0.05$ vs. AdGFP group or AdRFP group).

osteosarcoma cells may be mediated by the phosphorylation of p38 and JNK.

\section{Discussion}

Osteosarcoma is a high-mortality cancerous tumor localized at the end of metaphysis, which is most prevalent in children and young adults. Although early diagnosis and timely treatment have greatly enhanced the survival rates, the patients have a poor prognosis because of the high rate of lung metastasis and drug resistance (24). Tumor microenvironment, which contains large amounts of ECM generated by tumor cells including growth factors, chemotactic factors and matrixdegrading enzymes, is greatly associated with tumorigenesis, development and metastasis by influencing the proliferation, apoptosis, migration and invasion of tumor cells (25). As mentioned earlier, it is necessary to elucidate a novel strategy that efficiently inhibits the progression of osteosarcoma.
B MG63

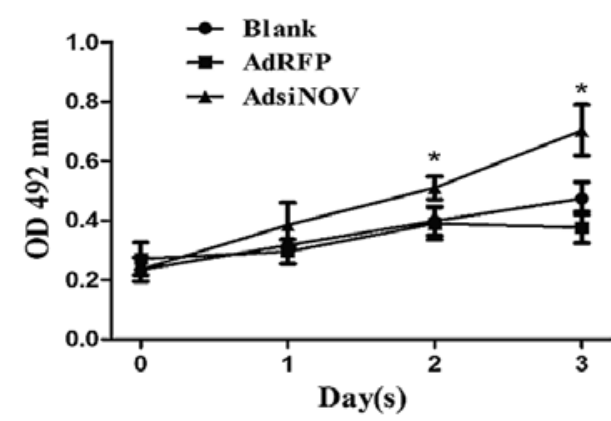

D
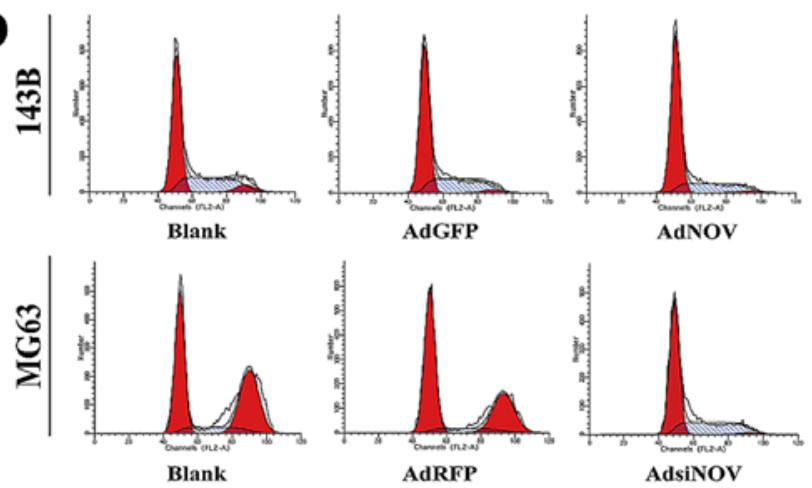

MG63
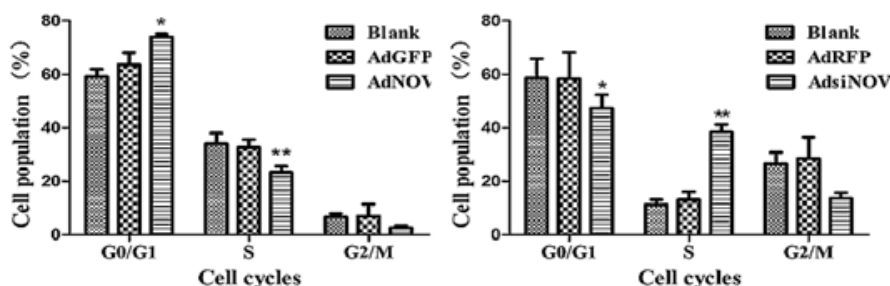

$\mathrm{NOV}$, also known as $\mathrm{CCN} 3$, is a matricellular protein encoded by the NOV gene, that can interact with numerous cell-surface receptors and participate in various pathological physiological activities including tumor (26-28). NOV interacts with the integrin receptor of cell surface to trigger intracellular signal transduction and activate downstream signaling pathways, thus regulate the occurrence and development of tumor. NOV has been shown to play different roles in various types of tumors. A previous study demonstrated that NOV expression was associated with the prognosis judgment of osteosarcoma (17). Nonetheless, the biological foundation of this effect and the exact role of NOV expression in the progression of osteosarcoma has not been extensively clarified. Therefore, in the present study, we investigated the effects of NOV on the proliferation, apoptosis and migration of osteosarcoma cells and the possible underlying mechanisms.

In the present study, we firstly evaluated the endogenous expression of NOV in human osteosarcoma cell lines through 

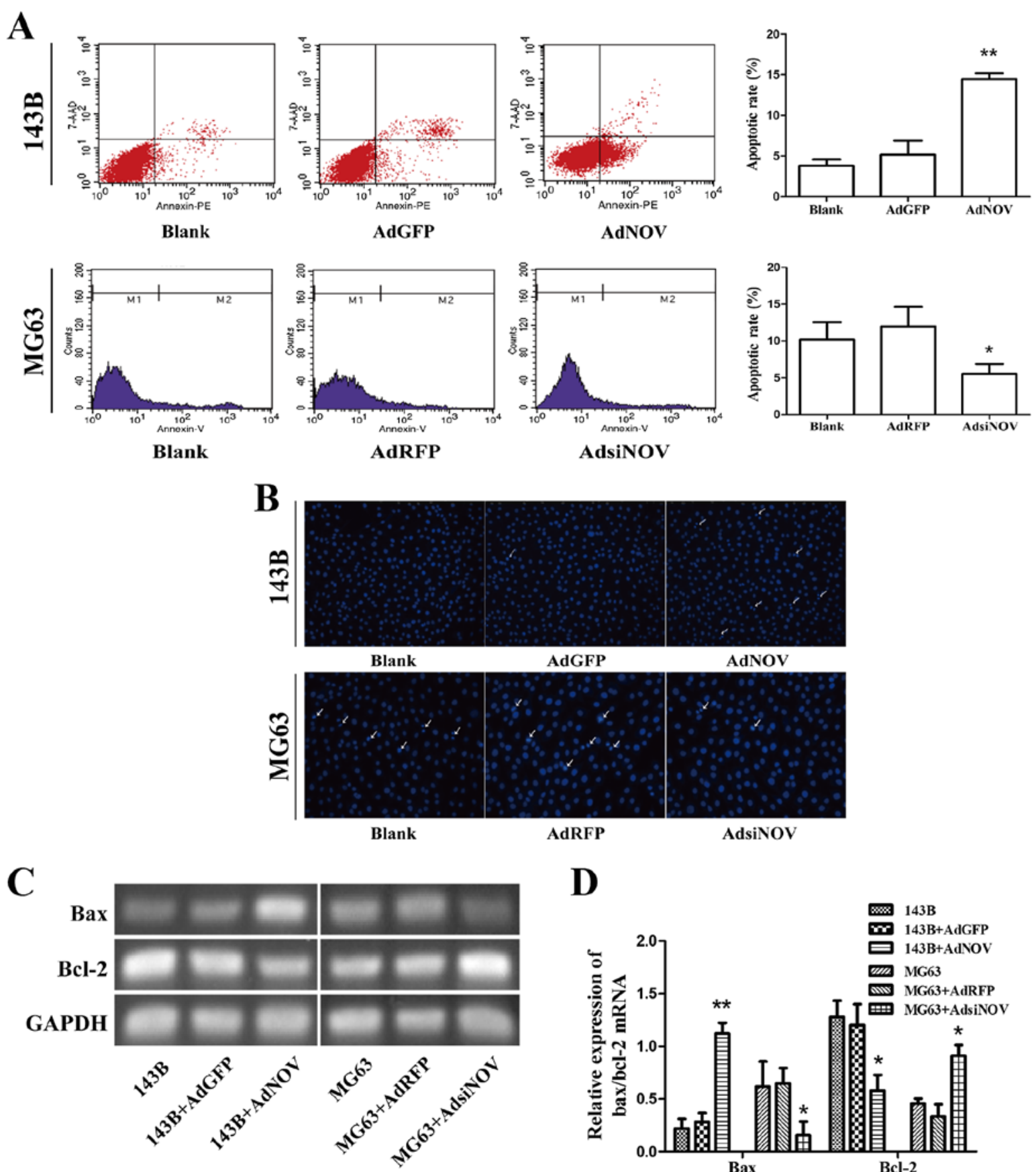

D
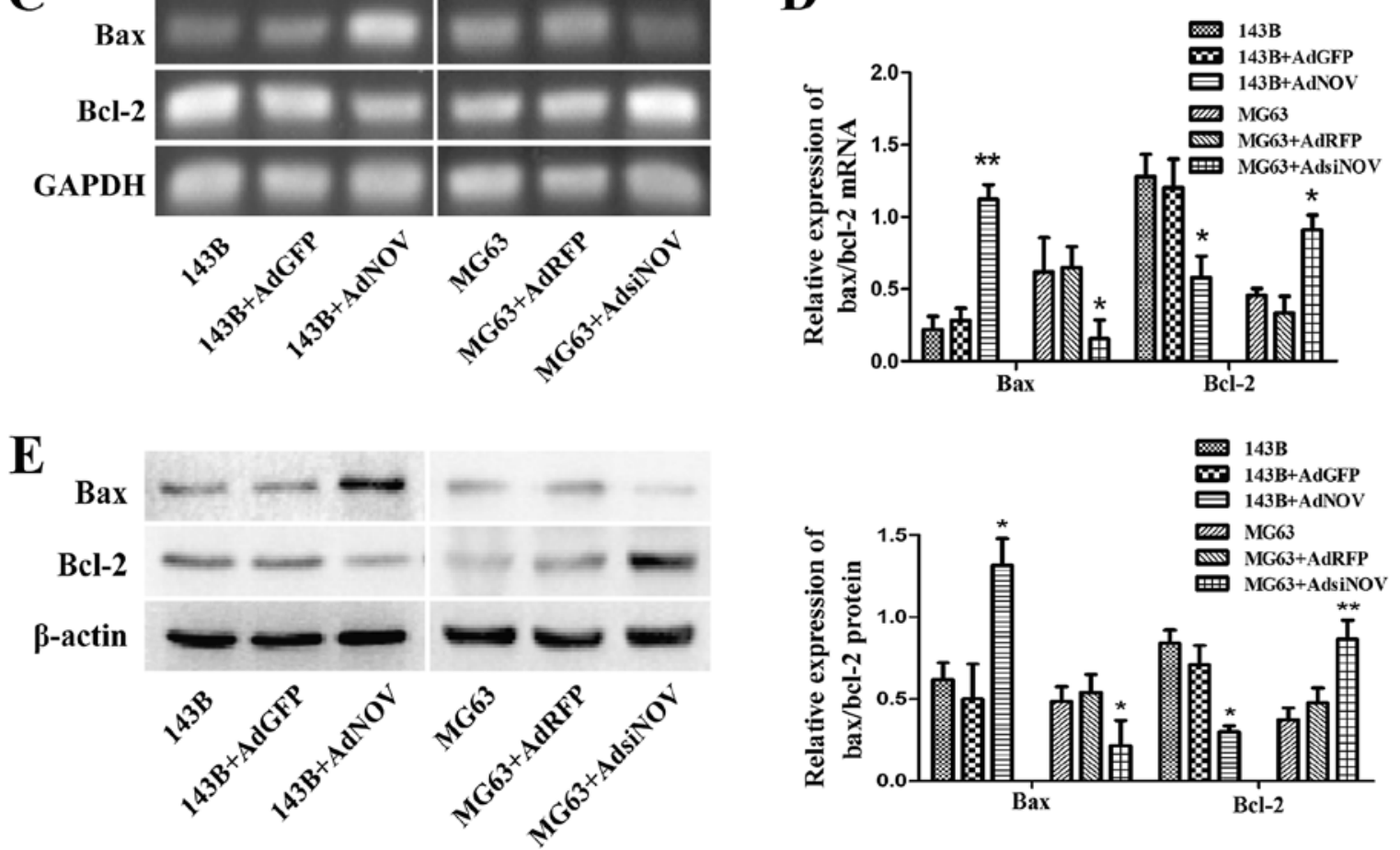

Figure 4. NOV induces apoptosis of osteosarcoma cell lines in vitro. (A) The 143B and MG63 cells were infected with AdNOV or AdsiNOV for $48 \mathrm{~h}$ and were then analyzed for apoptosis by flow cytometry. The percentage of apoptotic cells in 143B and MG63 cells for each group are quantified in the right panel. Values are the means $\pm \mathrm{SD}(\mathrm{n}=3)$. $\left({ }^{* *} \mathrm{P}<0.01\right.$ vs. AdGFP group, ${ }^{*} \mathrm{P}<0.05$ vs. AdRFP group). (B) At the end of the incubation period of $48 \mathrm{~h}$, the $143 \mathrm{~B}$ and MG63 cells were stained with Hoechst 33258 staining and the cell nucleus was observed under microscopy for apoptosis, showing that the number of apoptotic cells (strong blue staining) was significantly increased compared with the NOV overexpression group. Magnification, x100 (C) RT-PCR, (D) RT-qPCR and (E) western blot assays were performed at $48 \mathrm{~h}$ recovery to measure the expression of apoptosis-related proteins Bax/Bcl-2 in osteosarcoma cell lines. Data are shown as mean values \pm SD of three individual measurements. ( ${ }^{* *} \mathrm{P}<0.01$ and ${ }^{*} \mathrm{P}<0.05$ vs. AdGFP or AdRFP group). 

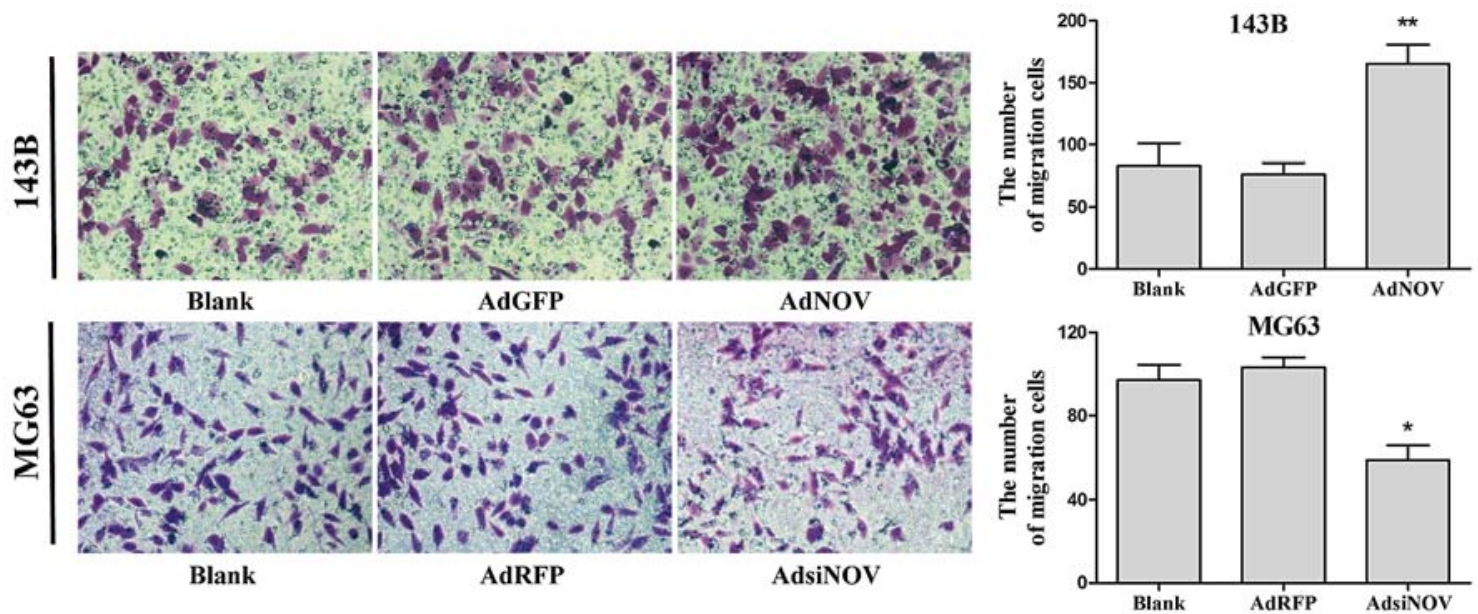

Figure 5. NOV promotes the migration of osteosarcoma cells. (A) Effects of NOV expression on the migration of 143B and MG63 cells was detected by Transwell migration assay; magnification, $\mathrm{x} 200$. Data are reported as mean values \pm SD of three individual measurements. The quantification data are shown on the right panel. ${ }^{* * *} \mathrm{P}<0.01$ vs. AdGFP group, ${ }^{*} \mathrm{P}<0.05$ vs AdGFP group).

A

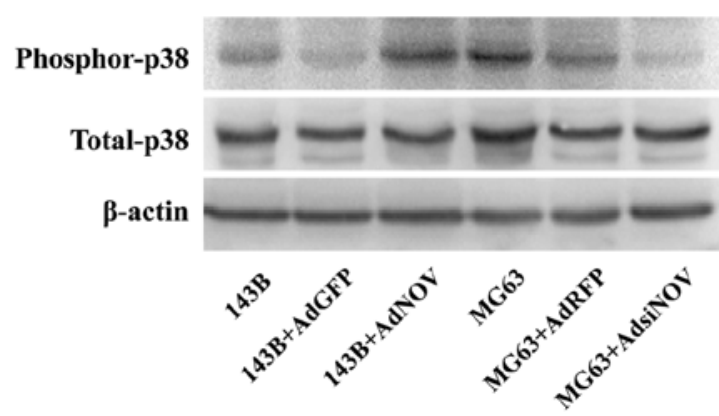

B

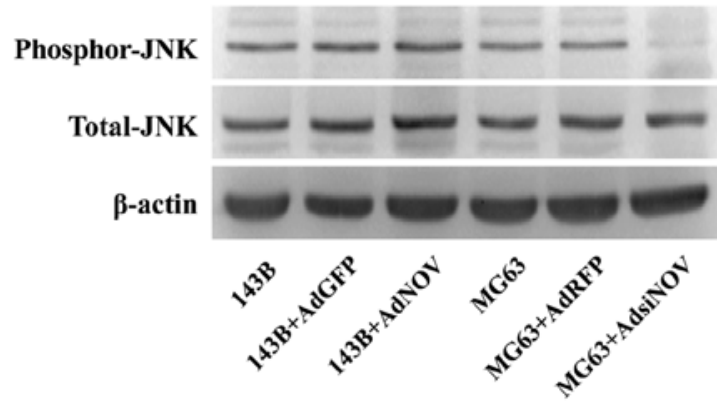

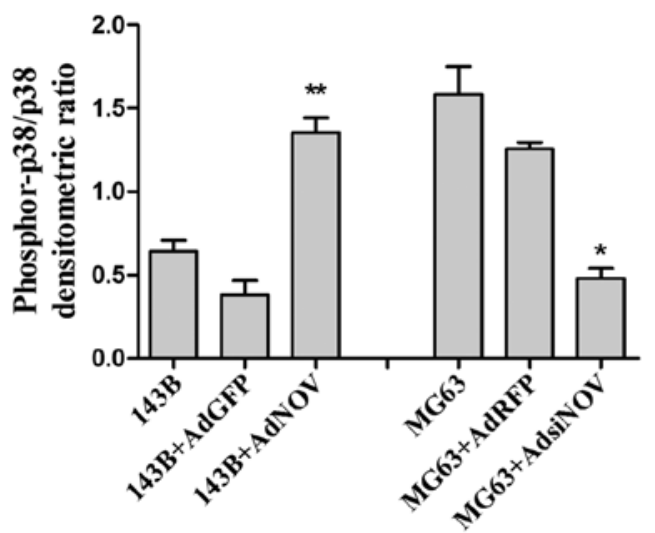

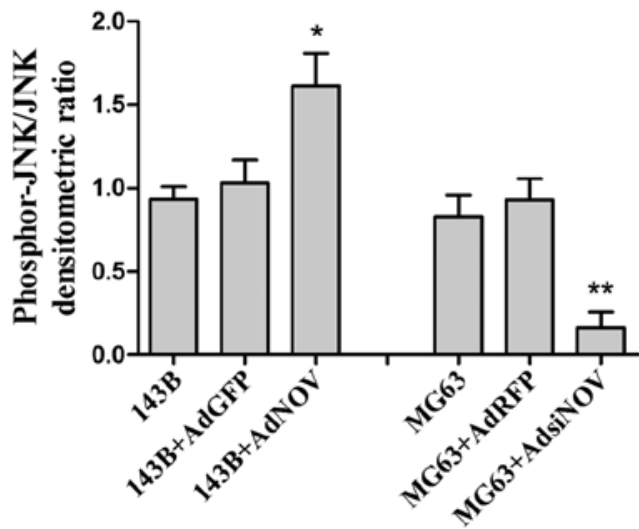

Figure 6. NOV activates the p38/MAPK and JNK/MAPK signaling pathway in osteosarcoma cells. (A) The phosphorylation levels of p38/MAPK and (B) JNK/MAPK in AdNOV-infected 143B cells and AdsiNOV-infected MG63 cells were detected by western blot analysis. Densitometric quantification data are on the right panel. Data are shown as mean $\pm \mathrm{SD}$ of three individual measurements. ( ${ }^{* * *} \mathrm{P}<0.01$ and ${ }^{*} \mathrm{P}<0.05$ vs. AdGFP group or AdRFP group).

PCR and western blot analysis and found it was different among the cell lines. Thus, we selected adenovirus-mediated NOV overexpression/downregulation to investigate the effects of NOV on different osteosarcoma cell lines. The present results showed that NOV overexpression had a significant inhibitory effect on osteosarcoma 143B cell viability in a time-dependent manner, whereas NOV silencing induced opposite effects in MG63 cells. These results have shown an inhibitory effect of NOV overexpression on cancer cell growth including renal cell carcinoma and Ewing sarcoma $(12,13)$, which is consistent with previous studies. A possible explanation for the growth inhibition is cell cycle arrest or apoptosis increase. Our results derived from FCM indicated that NOV overexpression may induce cell cycle arrest in the G1 phase in 143B cells, while its downregulation reversed the effect in MG63 cells, leading to increased cell proliferation ability. Since the G1 phase is necessary for the material and energy preparation for DNA replication into the subsequent $\mathrm{S}$ period, the abnormity of this 
A

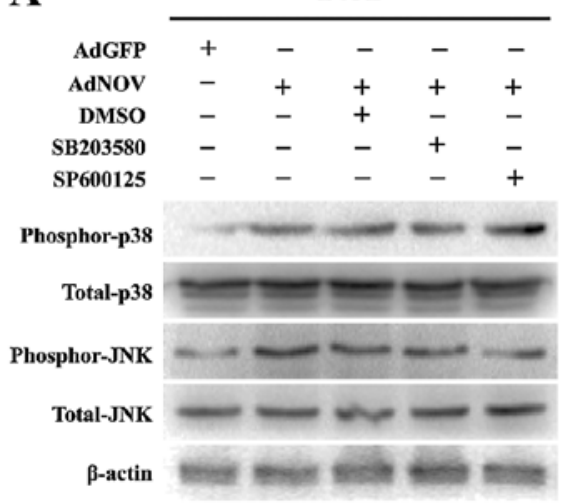

B
143B

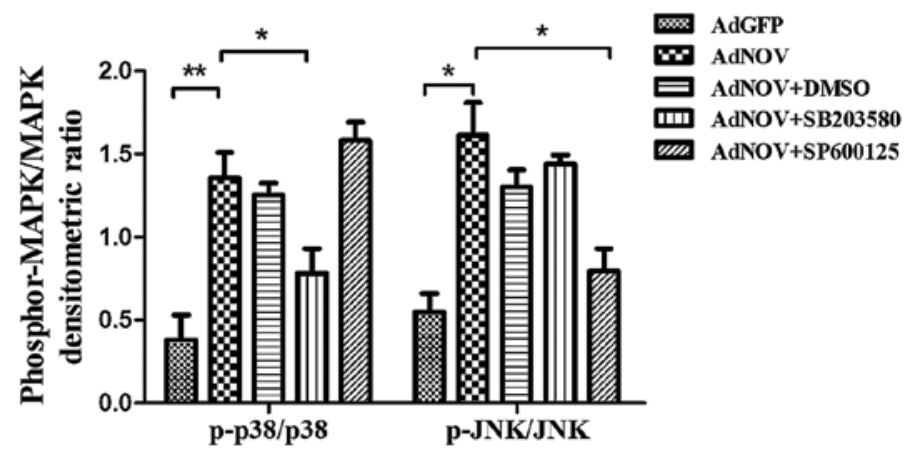

143B

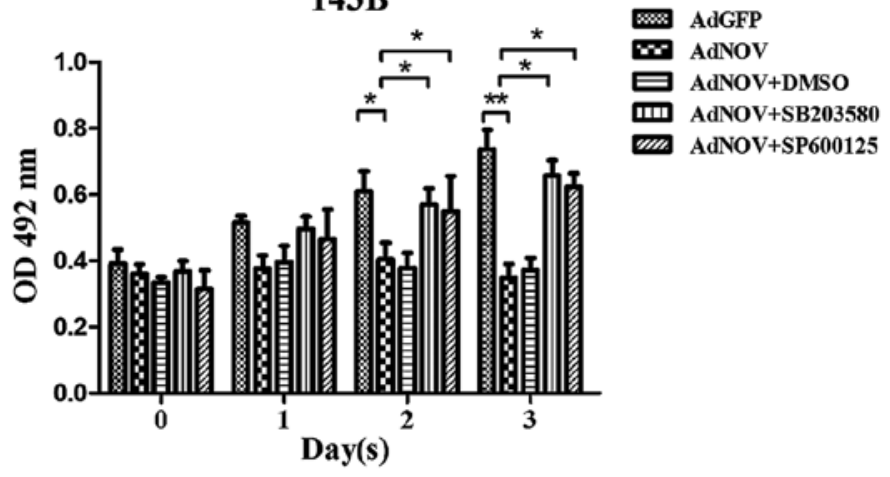

C

143B
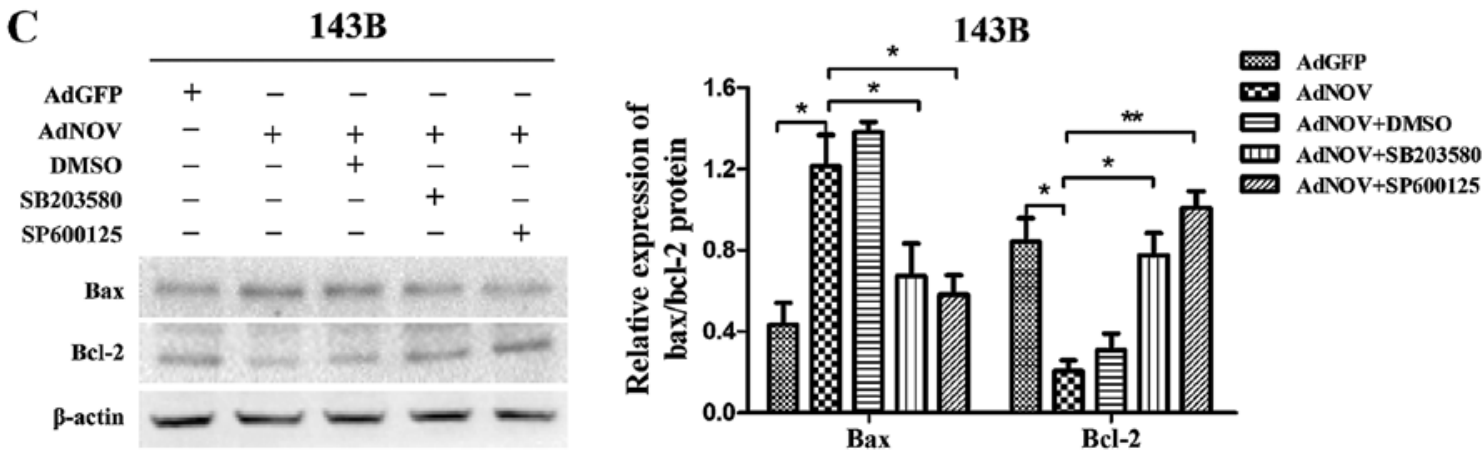

Figure 7. SB203580 and SP600125 suppresses NOV-induced apoptosis of 143B cells. (A) Effects of SB203580 and SP600125 on the NOV-induced activation of p38/MAPK and JNK/MAPK in 143B cells were detected by western blot analysis. The phosphorylation of p38 and JNK was reversed by SB203580 and SP600125, respectively; ${ }^{\mathrm{P}}<0.05$ vs. SB203580 group and SP600125 group. Densitometric quantification data are on the right panel. Data are shown as mean \pm SD of three individual measurements. (B) Effects of SB203580 and SP600125 on NOV-induced proliferation inhibition of 143B cells. Cell viability was measured by MTT assay. The inhibitory role of NOV in cell proliferation was reversed by SB203580 and SP600125. The results show the mean absorbance \pm SD of three independent experiments. ("P<0.05 vs. SB203580 and SP600125 groups). (C) The effects of SB203580 and SP600125 on the NOV-induced protein levels of Bax and Bcl-2 in 143B cells were detected by western blot analysis. The expression levels of Bax and Bcl-2 was reversed by SB203580 and SP600125, respectively. Densitometric quantification data are shown on the right panel. Data are shown as mean \pm SD of three individual measurements. ( $\mathrm{P}<0.05$ vs. SB203580 group and SP600125 group, ${ }^{* *} \mathrm{P}<0.01$ vs. SP600125 group).

phase may inevitably lead to the obstacles of DNA replication and eventually cause the inhibition of cell proliferation (29). At the same time, we found that NOV expression induced cell apoptosis of osteosarcoma cell lines. Bax and Bcl-2 are two primary proteins that are often used as markers for cell apoptosis $(30,31)$. Our results showed a marked increase of Bax and a decrease of Bcl-2 in the AdNOV group compared with the AdGFP and CON groups in 143B cells, but a decrease of Bax and an increase of Bcl-2 in AdsiNOV group compared with the AdRFP and CON groups in MG63 cells, further comfirming that NOV may promote the apoptosis of osteosarcoma cells.

P38/MAPK and JNK/MAPK are two major pathways for malignant progression in various tumors. It has been confirmed that they are involved in mediating apoptosis signals that cause cell death (32). Integrin receptor-dependent signaling pathways may activate P38/MAPK and JNK/MAPK, thereby promoting the phosphorylation of Bcl-2, the expression of Bax and induce the apoptosis of tumor cells $(33,34)$. Moreover, previous findings have shown that NOV induced cell apoptosis or growth inhibition in many types of cancer through activation of the MAPK signaling pathway $(35,36)$. Therefore, we detected the effects of NOV on the MAPK signaling pathway in osteosarcoma cell lines. Our results show that NOV expression enhanced the phosphorylation of $\mathrm{p} 38$ and JNK in osteosarcoma cells in vitro. Furthermore, the phosphorylation of p38 and JNK was inhibited by the specific inhibitors, 
SB203580 and SP600125, respectively. The results from the present study also demonstrate that NOV-induced cell proliferation inhibition and apoptosis was reversed by SB203580 and SP600125, suggesting that NOV is involved in osteosarcoma cell apoptosis by activating the MAPK signaling pathway. These results are consistent with those of previous findings for Ewing sarcoma (13).

Besides participating in the growth and prognosis, NOV also exerted effects on the adhesion, migration and invasion of tumor cells (7). Previous studies indicated that NOV activated PI3K/AKT and NF- $\mathrm{KB}$ signaling pathways by combining with $\alpha v \beta 3$ integrin receptor, thus promoting the transcription and expression of transfer relevant factors (37). Nonetheless, with regard to Ewing sarcoma, NOV overexpression reduced the expression of integrin $\alpha 2 \beta 1$ at the transcription level, thus reducing tumor cell anchor activity and promoting migration, and caused the abnormal distribution of MMP-9, leading to MMP-9 overexpression on the cell surface and promoting invasion (13). Our Transwell migration results demonstrated that the migration ability of osteosarcoma was greatly enhanced in 143B cells following NOV overexpression and markedly inhibited in MG63 cells after NOV silencing, which was consistent with previous findings for Ewing sarcoma. We hypothesized that the integrin receptor may also be involved in this progression, but whether it was consistent with Ewing sarcoma needs to be further examined. In combination with other clinical reports concerning NOV upregulation in primary osteosarcoma, it was identified that NOV overexpression has a close relationship with the high metastatic rate of osteosarcoma. Findings of previous clinical studies investigating the prognostic value of NOV including osteosarcoma patients receiving chemotherapy (17), showed that primary osteosarcoma cells with a low expression of NOV were easily eliminated using chemotherapeutic drugs due to their high proliferative capacity. By contrast, cells with NOV upregulation show hyposensitivity to drugs because of its lower proliferation and higher migration ability, thus making it possible for distant metastasis to occur. Therefore, NOV overexpression has a tendency to promote osteosarcoma progression in the clinic.

To the best of our knowledge, in the present study, we first confirmed that NOV expression can inhibit cell proliferation, while promoting the apoptosis and migration of osteosarcoma cell lines in vitro. We also demonstrated that NOV expression-induced phosphorylation of p38/MAPK and JNK/MAPK may be involved in these progressions. These results offer an experimental basis for further clarification of the effects of NOV on osteosarcoma and its probable mechanism. Furthermore, our results indicate that NOV overexpression may prove to be a valuable tool for inhibiting cancer growth. Future studies to elucidate the relationship between NOV and osteosarcoma are required.

\section{Acknowledgements}

We would like to thank Dr T.C. He of The University of Chicago Medical Center for providing the adenoviruses. This study was supported by the National Natural Science Foundation of China (NSFC 81102035) and Natural Science Foundation Project of Chongqing Science and Technology Commission (no.2011BB5126).

\section{References}

1. Damron TA, Ward WG and Stewart A: Osteosarcoma, chondrosarcoma, and Ewing's sarcoma: National Cancer Data Base Report. Clin Orthop Relat Res 459: 40-47, 2007.

2. Mirabello L, Troisi RJ and Savage SA: International osteosarcoma incidence patterns in children and adolescents, middle ages and elderly persons. Int J Cancer 125: 229-234, 2009.

3. Eyre R, Feltbower RG, Mubwandarikwa E, Eden TO and McNally RJ: Epidemiology of bone tumours in children and young adults. Pediatr Blood Cancer 53: 941-952, 2009.

4. Joliot V, Martinerie C, Dambrine G, Plassiart G, Brisac M, Crochet $J$ and Perbal B: Proviral rearrangements and overexpression of a new cellular gene (nov) in myeloblastosis-associated virus type 1-induced nephroblastomas. Mol Cell Biol 12: 10-21, 1992.

5. Perbal B: NOV (nephroblastoma overexpressed) and the CCN family of genes: Structural and functional issues. Mol Pathol 54: 57-79, 2001.

6. Chen CC and Lau LF: Functions and mechanisms of action of CCN matricellular proteins. Int J Biochem Cell Biol 41: 771-783, 2009.

7. Ouellet V, Tiedemann K, Mourskaia A, Fong JE, Tran-Thanh D, Amir E, Clemons M, Perbal B, Komarova SV and Siegel PM: CCN3 impairs osteoblast and stimulates osteoclast differentiation to favor breast cancer metastasis to bone. Am J Pathol 178: 2377-2388, 2011.

8. Scholz G, Martinerie C, Perbal B and Hanafusa H: Transcriptional down regulation of the nov proto-oncogene in fibroblasts transformed by p60v-src. Mol Cell Biol 16: 481-486, 1996.

9. Chevalier G, Yeger H, Martinerie C, Laurent M, Alami J, Schofield PN and Perbal B: novH: Differential expression in developing kidney and Wilm's tumors. Am J Pathol 152: 1563-1575, 1998.

10. Manara MC, Perbal B, Benini S, Strammiello R, Cerisano V, Perdichizzi S, Serra M, Astolfi A, Bertoni F, Alami J, et al: The expression of ccn3(nov) gene in musculoskeletal tumors. Am J Pathol 160: 849-859, 2002.

11. Yu C, Le AT, Yeger H, Perbal B and Alman BA: NOV (CCN3) regulation in the growth plate and CCN family member expression in cartilage neoplasia. J Pathol 201: 609-615, 2003.

12. Liu S, Liu Z, Bi D, Yuan X, Liu X, Ding S, Lu J and Niu Z: $\mathrm{CCN} 3(\mathrm{NOV})$ regulates proliferation, adhesion, migration and invasion in clear cell renal cell carcinoma. Oncol Lett 3: 1099. $1104,2012$.

13. Benini S, Perbal B, Zambelli D, Colombo MP, Manara MC, Serra M, Parenza M, Martinez V, Picci P and Scotlandi K: In Ewing's sarcoma CCN3(NOV) inhibits proliferation while promoting migration and invasion of the same cell type. Oncogene 24: 4349-4361, 2005.

14. Liu C, Liu X-J, Crowe PD, Kelner GS, Fan J, Barry G, Manu F, Ling N, De Souza EB and Maki RA: Nephroblastoma overexpressed gene (NOV) codes for a growth factor that induces protein tyrosine phosphorylation. Gene 238: 471-478, 1999.

15. Ren Z, Hou Y, Ma S, Tao Y, Li J, Cao H and Ji L: Effects of CCN3 on fibroblast proliferation, apoptosis and extracellular matrix production. Int J Mol Med 33: 1607-1612, 2014.

16. Owen TA, Aronow M, Shalhoub V, Barone LM, Wilming L, Tassinari MS, Kennedy MB, Pockwinse S, Lian JB and Stein GS: Progressive development of the rat osteoblast phenotype in vitro: Reciprocal relationships in expression of genes associated with osteoblast proliferation and differentiation during formation of the bone extracellular matrix. J Cell Physiol 143: 420-430, 1990.

17. Perbal B, Zuntini M, Zambelli D, Serra M, Sciandra M, Cantiani L, Lucarelli E, Picci P and Scotlandi K: Prognostic value of CCN3 in osteosarcoma. Clin Cancer Res 14: 701-709, 2008.

18. Kuo WH, Chen JH, Lin HH, Chen BC, Hsu JD and Wang CJ: Induction of apoptosis in the lung tissue from rats exposed to cigarette smoke involves p38/JNK MAPK pathway. Chem Biol Interact 155: 31-42, 2005.

19. Mansouri A, Ridgway LD, Korapati AL, Zhang Q, Tian L, Wang Y, Siddik ZH, Mills GB and Claret FX: Sustained activation of JNK/p38 MAPK pathways in response to cisplatin leads to Fas ligand induction and cell death in ovarian carcinoma cells. J Biol Chem 278: 19245-19256, 2003.

20. Chen HJ, Lin CM, Lee CY, Shih NC, Peng SF, Tsuzuki M, Amagaya S, Huang WW and Yang JS: Kaempferol suppresses cell metastasis via inhibition of the ERK-p38-JNK and AP-1 signaling pathways in U-2 OS human osteosarcoma cells. Oncol Rep 30: 925-932, 2013. 
21. Tsagaraki I, Tsilibary EC and Tzinia AK: TIMP-1 interaction with $\alpha v \beta 3$ integrin confers resistance to human osteosarcoma cell line MG-63 against TNF- $\alpha$-induced apoptosis. Cell Tissue Res 342: 87-96, 2010.

22. Luo J, Deng ZL, Luo X, Tang N, Song WX, Chen J, Sharff KA, Luu HH, Haydon RC, Kinzler KW, et al: A protocol for rapid generation of recombinant adenoviruses using the AdEasy system. Nat Protoc 2: 1236-1247, 2007.

23. He TC, Zhou S, da Costa LT, Yu J, Kinzler KW and Vogelstein B: A simplified system for generating recombinant adenoviruses. Proc Natl Acad Sci USA 95: 2509-2514, 1998.

24. Jemal A, Bray F, Center MM, Ferlay J, Ward E and Forman D: Global cancer statistics. CA Cancer J Clin 61: 69-90, 2011.

25. Fidler IJ: The pathogenesis of cancer metastasis: The 'seed and soil' hypothesis revisited. Nat Rev Cancer 3: 453-458, 2003.

26. Perbal B: The CCN3 protein and cancer. In: New Trends in Cancer for the 21st Century. Springer, pp 23-40, 2006.

27. Denduluri SK, Idowu O, Wang Z, Liao Z, Yan Z, Mohammed MK, Ye J, Wei Q, Wang J, Zhao L, et al: Insulin-like growth factor (IGF) signaling in tumorigenesis and the development of cancer drug resistance. Genes Dis 2: 13-25, 2015.

28. Perbal B: CCN proteins: A centralized communication network. J Cell Commun Signal 7: 169-177, 2013.

29. Bartek J and Lukas J: Mammalian G1- and S-phase checkpoints in response to DNA damage. Curr Opin Cell Biol 13: 738-747, 2001.

30. Yin X-M, Oltvai ZN and Korsmeyer SJ: BH1 and BH2 domains of $\mathrm{Bcl}-2$ are required for inhibition of apoptosis and heterodimerization with Bax. Nature 369: 321-323, 1994.
31. Kroemer G: The proto-oncogene Bcl-2 and its role in regulating apoptosis. Nat Med 3: 614-620, 1997.

32. Wagner EF and Nebreda ÁR: Signal integration by JNK and p38 MAPK pathways in cancer development. Nat Rev Cancer 9: 537-549, 2009.

33. De Chiara G, Marcocci ME, Torcia M, Lucibello M, Rosini P, Bonini P, Higashimoto Y, Damonte G, Armirotti A, Amodei S, et al: $\mathrm{Bcl}-2$ phosphorylation by $\mathrm{p} 38$ MAPK: Identification of target sites and biologic consequences. J Biol Chem 281: 21353-21361, 2006.

34. Nicholson DW and Thornberry NA: Apoptosis. Life and death decisions. Science 299: 214-215, 2003.

35. Doghman M, Arhatte M, Thibout H, Rodrigues G, De Moura J, Grosso S, West AN, Laurent M, Mas JC, Bongain A, et al: Nephroblastoma overexpressed/cysteine-rich protein 61/connective tissue growth factor/nephroblastoma overexpressed gene-3 (NOV/CCN3), a selective adrenocortical cell proapoptotic factor, is downregulated in childhood adrenocortical tumors. J Clin Endocrinol Metab 92: 3253-3260, 2007.

36. Gupta N, Wang H, McLeod TL, Naus CC, Kyurkchiev S, Advani S, Yu J, Perbal B and Weichselbaum RR: Inhibition of glioma cell growth and tumorigenic potential by CCN3 (NOV). Mol Pathol 54: 293-299, 2001.

37. Chen PC, Cheng $\mathrm{HC}$ and Tang $\mathrm{CH}$ : $\mathrm{CCN} 3$ promotes prostate cancer bone metastasis by modulating the tumor-bone microenvironment through RANKL-dependent pathway. Carcinogenesis 34: 1669-1679, 2013. 